Recent work in the social studies of science has emphasized the importance of studying both the social and cognitive aspects of the evolution of scientific specialties and disciplines. This has implications for science policies timat aim at the direction of scientific fields toward external goals: the cognitive state and dynamics of the fielc have to be taken into acount. Such a cognitive approach to science policy has been elaborated by a number of German science scholars. The three-phase model of scientific developn ents and the tinalization thesis of the Starnberg group is discussed, and the policy implications are critically reviewed. A group based in the University of Bielefeld has published case studies designed to trace the role of :ognitive factors in explaining the impac: of science pulicy programmes on scientific fields. It turns out that mutual adaptation processes occur in the cours: of formulating the programmes which reduce conflict and resistance. In conclusion, son s. jospectives for further work are noted. 


\title{
A COGNITIVE APPROACH TO SCIENCE POLICY
}

\author{
Arie RIP \\ Gorlaeus Laboratoria der Rijksuniversiteit te Leiden, Postbus 9502, 2300 RA, \\ Leiden, The Netherlands
}

\section{Introduction}

Science policy has devoted itself to the problems of organization and of allocation of money [1]. Although scientific advisers are called in to review the stat? of a science and its potential for new and useful developments, the substance of science has normally been out of bounds for policy making. Such a set-up is legitimated by, and through its continued existence supports, the view that science, which concerns cognition, has no intrinsic connection with politics, which concerns power.

The limits to growth of the science budgets, as well as pressing technological and social problems, have led policy makers to take a second look at this division of territory. More or less at the same time, developments in the history, sociology and philosophy of science occurred emphasizing the necessity of looking at social and cognitive aspects of science together; one example is the renewed discission and study of the role of external factors in the development of science. When it is also realized that politics is not only the play of power and clashes of interests, but also includes cognitive aspects like assessments of situations and outcomes, reasons for goals and priorities, etc. the orginal contrast between cognition and power is amplified to a $2 \times 2$ matrix (see fig. 1).

Because of the interactions within the rows and columns of the matrix of fig. 1, external influence on science is possible, decisions in the political sphere eventually affecting the outcomes of scientific research. From this perspective, insight into the cognitive, as well as social state of a science becomes a prerequisite for a wise policy. Recent work in the social studies of science has made the 'black box' of science and the dynamics of its develop- 


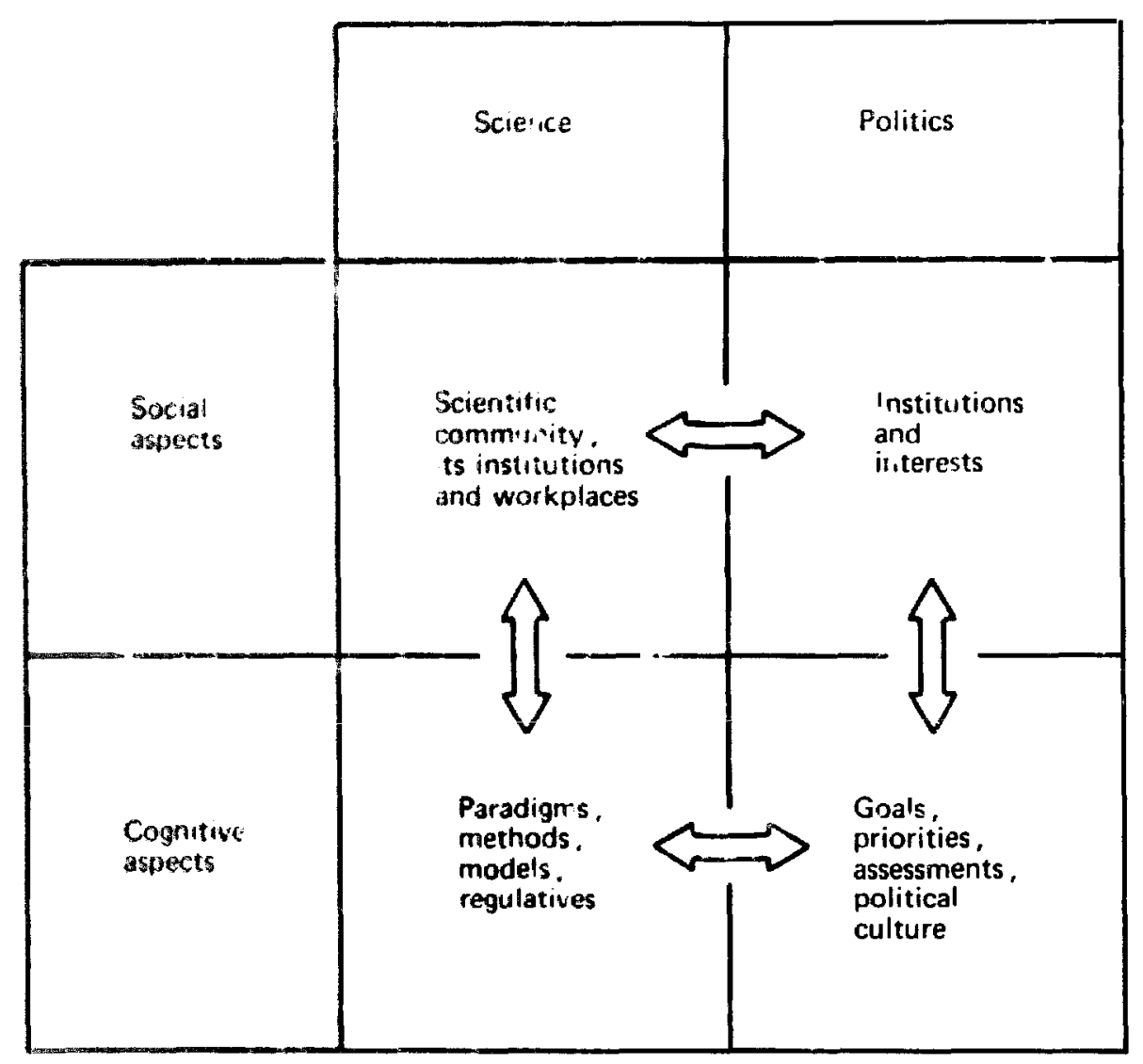

If. I. The sockal and cognitive aspects of science and politics.

Incmis somewhat translucid, thus providing material for what I shall call a cogntive approach to science policy.

Often, socul studies of scienc are not designed with any science-policy relevance in mind. A group of i jerman science scholars (Wissenschaftsförsile.), formerly based at the $\mathbf{M}: \times$ Planck Institut in Starnberg, has made a concrted attempt to construc* a model of the development of science with explicit policy iniplications $12-4 \mid$. Using the same ccgnitive approach, some nembers $u^{\prime}$ this group liave collahorated with science scholars from the University of Bielefeld in analysing the inpact of policy measures on the development of sciences $\{5.6\}$. In this paper I give an outline of some main points an' a critical review of the two recent books, Die gesellschaftliche OrienIit nung des wissens haftichen Fortsciritts [4] and Geplante Forschung [6]. To set the scene, I shall briefiy refer to recent trends in the social studies of sience. 


\section{The dynamics of the development of science}

Fig. 2 shows how Thomas Kuhn's model of the paradigm-guided development of science has led to a flood of research in the social studies of science. A lot of empirical material on the development of scientific specialties and research areas has been accumulated [7], with some attempts at systematizition [8]. Separate approaches that can be distinguished at the moment aie scientonetrics, especially with the relp of citation analysis [9] an anthropo-

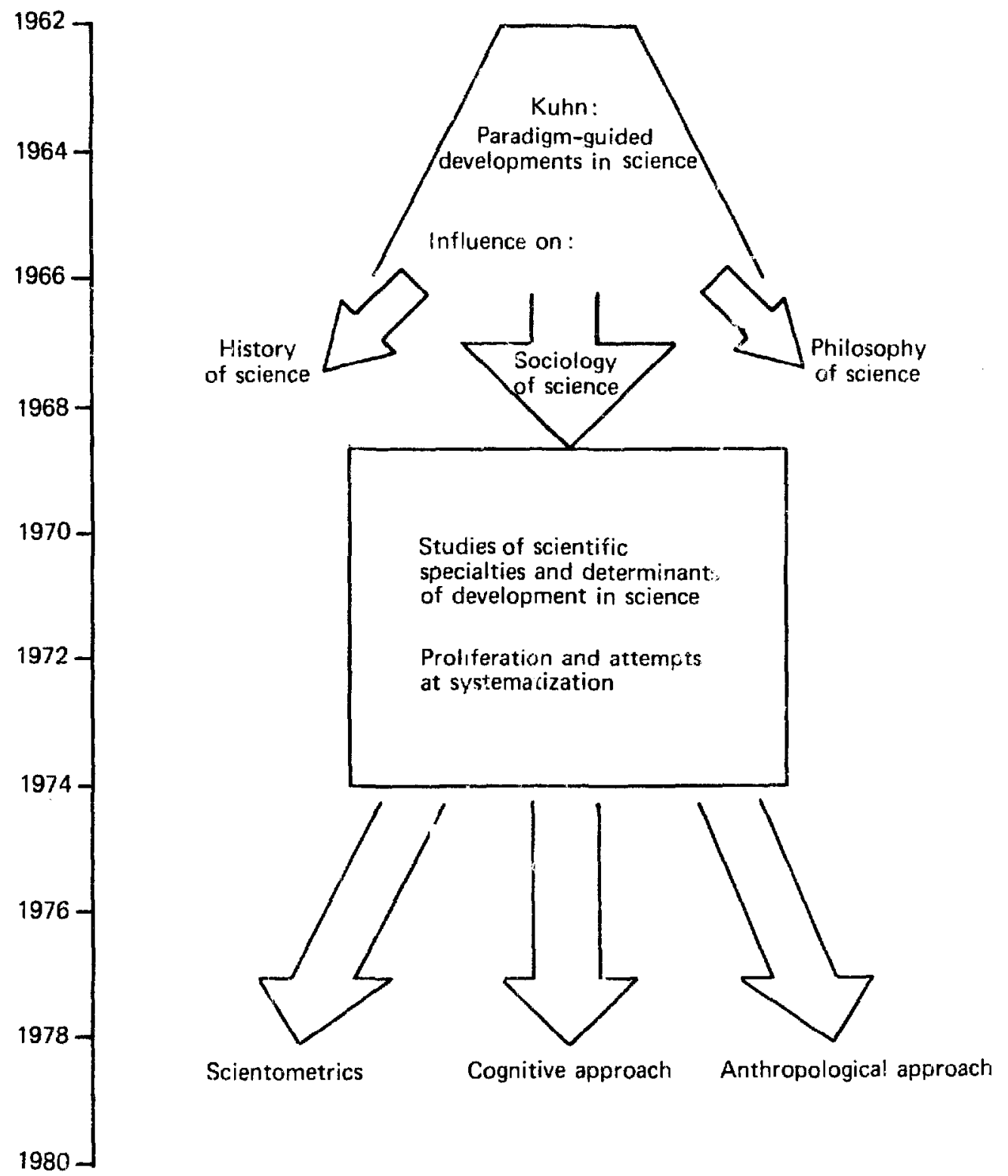

Fig. 2. Recent trends in the study of the dyramics of science. 
logical approach [10], and a cognitive approach, wher' the cognitive developments are not treated as a black box, but are amenable to sociological analysis [1i].

Kuhn [12] has shown, on the basis of historical evicence, that the develop. ment of science proceeds with periods of normal suience - where scientists in a discipline or specialty share a common paradigm ard work towards its fur. ther articulation and refirement - alternating with periods of revolutionary science - wheie concern about anomalies and proposals for alternative paradigms throw the discipline into a crisis until one of the alternatives wins out and a new period of normal science ensues. The paradigm provides cognitive norms or regulatives for ongoing research in a discipline, and through the shared commitments of the members of the discipline also a sense of community. According to Kuhn, successive paradigms are in a sense incommensurable, and the transition between them requires a Gestalt switch that is likened to a conversion.

Altheugh the function of a paradigm in providing regulatives for research and building a disciplinary community has been widely accepted, the other features of Kuhn's model have not. Paradigms, even if they are called 'central dognas', inay te abandoned without fight or crisis symptoms [13]. The incommensurability thesis has been a challenge to the philosophy of science to come up with new theories of rational progress in science [14]. The Starnburg group has pointed out that old paradigms may sometimes live on besides their successor and continue to be used, although with a clear sense of their li nitations. Their criticism of Kuhn is a stepping-stone toward their own nindel for the development of science.

The paradigm of classical mechanics, although replaced by relativistic mechanics, and on the molecular and atomic level by quantum mechanics, is sili valid for most purposes, and has a certain self-sufficiency that leads us to expect that it will remain valid. Heisenberg has introduced the notion of a 'closed theory' to describe such cases, and the Starnberg group has tried to develop more precise criteria for such cognitive stability [15]. From the example of classical mechanics, and others like electromagnetism, whermodyramics, and molecular chemistry, they conclude that paradigms may become mature: the regulatives for research are no longer directed to articulation or the paradigm, but toward application and specification for new or inore complex obje $t$ domains. Examples would be thermodynamics of iiving systems, mechanicis and electrodynamics of plasmas.

A second difference with Kunn's model is that the Stanberg group recognizes that the pre-paradigmatic stage, mentioned by Kuin, has its own characteristic research strategies, and can be recognized in many contemporcry 
disciplines (for instance, microbiology until quite recently, medical and public health science). The Starnberg group thus distinguishes three possible cognitive states of scientific disciplines, and in addition claims that they represent successive phases in their historical development [6, pp. 13-16].

(1) Exploratory phase. There is as yet no theory that organizes the field, empirical, trial-anderror strategies abound, discovery is more important than explanation.

(2) Paradigm phase. A fundamental (grun!llegende, i.e. fundamental with respect to the domain of the specialty) theory is proposed, accepted and articulated further. The problems possd by such theory development regulate the activities within the field and so lake precedence over other concerns. Kuhnian revolutions or gradual evolution may exchange one fundamental theory for another, but theoretical explanation remains the overriding concern.

(3) Post-paradigmatic phase. The fundamental theory is stable (according to cognitive and/or social criteria) and the mature paradigm can be exploited for other goals, internal or external to science.

The policy implications of the Starnberg model for the development of sciences are bound up with the value the Starnberg group attaches to developments in the third, post-paradigmatic phase. Compared with the paradigm phase, the internal regulatives lose much of their force and there is room for external regulatives, i.e. external goals that are translated into guidelines for research and specific theory development. The river of science has, as it were, reached its delta and can now be made to change its course very easily. The internalization of external goals is called finalization, and the resulting specialized developments are called finalized specialties or discipiines [3; 16, pp. $210-220 ; 17]$.

An example of a finalized discipline is hydrodynamics, a branch of physics in which classical mechanics is developed specifically to account for the phenomena of flow. New theory development is necessary because the equations of classical mechanics cannot be solved for the complex processes of flow. Vital to the specialized development is the introduction of a guiding concept (Anwendungsgrunclaise), in this case the concept of a boundary laj ar adhering to objects or surfaces along which the flow passes. Around this concept, the basic equations of hydrodynamics are built up, and the resulting theory continues to apply the conceptual apparatus of classical mechanics, is legitimated by it, but canoot be derived from it [19]. The regulatives of hydrodynamics are external to classical mechanics, although they cas be considered to be internal to physics. Historically, they are related to attempts to systematize the technical knowledge of hydraulics [20].

Another example is provided by plasma physics, itself a specialized devel- 
opment from mechanics and electrodynamics to treat the thehaviour of ionized gases in electromagnetic fields (plasmas). Again, guiding concepts are necessary, e.g. to obtain the equations of magnetohydrodynarnics. External goals have provided additional regulatives in the specialty of thermonuclear fusion research, where the behaviour of plasmas in specific geometries and with surface effects are treated. The specialty was born during the 1950s, when the crash progranıme to develop a fusion reactor failed and fundamental knowledge had to be gained to advance further. The external economic goal of delivering energy dictated possible geometries, as well as the inclusion of the effects from the walls of a reactor. Having become regulatives of the new specialty, they didn't need to be enforced by management, but were integrated in the workings of the scientific community of the specialty [21].

The last example sho'ws why the Starnberg group emphasizes the importance of finalization. In finalized specialties, a middle-of-the-road alternative appears to be realized between the extreme positions in the science policy debate, namely complete autonomy of scientists versus centralistic planning. In principle the research can proceed autonomously because the external policy goal is internalized as a regulative in the specialized paradigm of the of the finalized specialty. In practice, additional direction will often be necessary [22], while the creation of such a paradigm is not a trivial problem but a scientific challenge by itself.

When a discipline does not possess a mature paradigm, firialization is not possible. Attempts to direct the development toward external goals cannot profit from the insight into the nature of the object domain that is provided by a stable fundamental theory, and are called functionalization by the Starnberg group. Screenirig for functions and input-output relationships would be functional strategies. An example would be the screening of chemical substances for pharmacological effects, while a more theory-oriented strategy would be to develop structure-activity relationships to find explanations of the effects in terms of mechanisms. Other examples of functionalized disci. plines are econometric modelling, based on extrapolation of trends, and system dynamics (e.g. Forrester and Meadows world dynamics).

According to the Starriberg model, functionalization is easy in the exploratory phase of a discipline, because then there are no st cong internal regulatives that compete with the external direction. In the paradigmatic phase, scientists resist external direction and it may be argued that external direction .n this phase is counter-procuctive. Here, as with the notion of maturity or ripeness of a discipline, the Starnberg group takes over the ':ommon sense' of scientists in fundamental scientific research: functionalization is condemned us overexploitation of a scientific discipline. They also poirt to tha danger of 
un ritical uses when a fundamental theory lacks or is neglected [16, pp. 234 240].

The policy implications of the Starnberg model can now be surnmarized as a twofold advice: science scholars should diagnose the cognitive state of a discipline, and then policy makers should decide on light exploitation in the exploratory phase, stimulation in the paradigm phase, and finalization toward suitable ends in the pcist-paradigmatic phase. These implications have been drawn by the Starnberg group members, and have led to acrimonious and often misdirected debate [23]. It should be noted, however, that the policy implications are progra nmatic: the Starnberg group itself has not analysed the effectiveness of policy measures in relation to the cognitive state of the disciplines concerned, but has concentrated on historical studies illustiating and further articulating their views on the development of science $[19,24-$ 27j.

Attempts to make the policy implications ntore operational will face the difficulty that the concept of finalization is still rather vague (as has been noted by others [28]; in my presentation I have emphasized one possible interpretation in terms of guiding concepts; compare also [17]) and that it does not seem possible for science scholars to determine the maturity of a field unless they accert the judgement of the scientists working in it [29]. But these scientists, or the elite that frequents scierce policy circles, are already consulted on ine issue of the ripeness of the field in many cases, so there seems to be no special role for the science scholar except that he may contribute a non-interested opinion. In fact, when diagnosing the state of a discipline, the Starnberg group uses an implicit criterion of maturity, namely a reductionist relation to the central theories of physics, and more specifically, a 'micro-theoretical' explanation of phenomena, i.e. in terms of invisible particles and their interactions. The reductionist slant has been noted by others [28, p. 333] and is apparent in some of the articles (e.g. [3, pp. 310 311]). The micro-theoretical explanation is explicitly used as a criterion of maturity in the analysis of the disciplines contributing to cancer research [30] and to biotechnology [31], and mentioned in passing in [6, p. 42]. Symes has noted the same point, and tried to build a definition of maturity on it [32, esp. pp. 339-340].

For policy makers interested in manipulation and control, the Starnberg model has little to offer. The identification of finalization and the conditions of its occurrence provides better insight into the working of contemporary science, but no direct policy advice. Furtinermore, the model cannot be generalized very far; technological disciplines and 'formal' disciplines (like mathe. matics, computer science) may show three phases, but even then have differ- 
ent types of regulatives. And many important cases of problem-oriented researcl do not fit the pattern because the main issue is the integration of different discipiinary contributions (compare the case stucies in [6], and the examplas, as well as the general argument of [33]).

Viewed as a tirst attempt, however, the Starnberg model fares bettel, and some more modest uses can be noted. Although the Starnberg group did not follow up the possibility, the importance of fundamental research is, in their model, not a selief or ideology but an arguable and particlly researchable proposition. If one accepts the reductionist view, contributions of different disciplines to the solution of a problem can be assessed and coriesponding policy measures deviseo [34]. An important result of the work of the Starnberg group is also that they have developed a vocabulary to analyse cognitive developments that is adapted to the language of science policy. The case study of fusion research programmes in the US and FRG profits from the use of the concepts of internal and exiernal regulatives, [35] while functionalization and Anwendungsgrundlage can be applied in anaiysing biotechnology [31.36]. Surveys and perspective reports of scientific disciplines will improve their analysis and recommendations by explicitly using such cognitivepolicy language, as can be illustrated in the case of chemistry [37].

As a concrete example of the use of the Starnberg model, I present some results of Hohlfeld's analysis of the cognitive state of cancer research [30]. Table I shows his diagnosis of the cognitive state of contributing disciplines. Looking more closely at the possibilities for mission-orientation of disciplines in the second, paridigm pl ase, Hohlfeld notes two research policy strategies; coincidence researsh and Iransfer research. (Examples are given in tabel 2.) In coincidence research, a system relevant to the overall mission (in this case, cancer prevention, control and therapy) is sufficiently manageable and represent rive to be used in the laboratory to develop the fundamental theory. The 'dirry' systems normally found in practice can sometimes be studied using results obtained on model systems as guidelines. Attempts to articulate and modify such guidelines are called transfer research. The practice of coincidrnce research and transfer research has, I am sure, been part of the folk wisdom of research management for a long time. Their conceptualization in terms of a model of scientitic development is the first step to further rationalization. The assessment of the contributing disciplines may also be useful, but it is harder to draw crenclusions nere, because Hohlfeld does not use his assessmen! when studying the cancer reseach programmes in the US and FRG [38] (but compare [3.4]).

Another use of a first model for the development of disciplines and its policy implications is that it leads to improved models. One would expect 
Table 1

Disciplinary contributions to cancer research

From stable theories

- pathological anatomy (classification of tuniours)

- chemistry (identification of carcinogens)

- classical genetics (somatic mutations)

-- biochemistry (metibolism of tumour cel!s)

From theories $b$ ing articulated

- molecular biology of cells of higher organisms

-- devel spmental biology of cells, tissues, organs

From fields in an exploratory phase

- human biology

- medical science

- public health science

Table 2

Mission-orientation of fundamental research (examples from cancer research)

Coincidence research

- differentiation in the system of hemopoietic (blood-building) cells, including malignant growth and its effects

- induction of dif terentiation in lymphocytes by immunological reactions, including reactions to tumour cells

Transfer research

in-vitro cultures it 'dirty' systems, e.g. lung cancer tumours

the case studies of science policy programmes in FRG [6] to be an occasion to apply and refine the model. Although the vocabulary is used in some case studies, 'finalization' is never mentioned - because of the controversies that have sprung up around it, I suppose; compare [23] - and thu model is used sparingly, if at all. The emphasis of the book is on the resistance and receptivity of scientific developments toward political direction.

\section{The political direction of science}

In Geplante Forschung, the question of the cognitive conditions for successful mission:orientation of scientific disciplines is tackled from the empi:cal side. The cases selected for analysis have to extend beyond the applica. tion of existing knuwledge; the policy goals have to be attained by institu- 
tuc nalization of st ecial scientific developments, i.e. new specialities or research fronts will their own dynamics. The empirical question is about the condiin os of success of a dynamic initiated through the political direction of sciense which implies that finalization may or may not turn out to be the labu of one of the successful dynamics. In fact, the frame of reference of the sas studis is not the Starnberg model for the development of disciplines, but a theoretical study by van den Daele and Weingart on the resistance and Hexptivity of science to external direction [5].

The case studies look at biotechnology, information science, cancer research, cavirommental research, thermonuclear-fusion research and heavy. whis resarsh. and have been sulecied because these fields have been subjected to explicit sience policy prograns by the German federal government. Such a selection is necessary 10 distinguish between general promotion of science and astual direction, and to provide an empirical basis for the identification ot the content of the political direction. The study would then proceed by atalysing the mechanisms of the transformation of the external goals into regulatives of the research process, and by o'serving svmptoms of resistance, it any, to the external regulatives [6, pp. 239-.20]. From the detailed study of the case a judge nent has to be derived whether the resistance is institufonal (c. Itaditions, inertia of organizations) or cognitive (cognitive deficits, conflici with intemal dynamics). Successful political direction is defined as we achievenent of a change of directirn of the scientific developments, not 1") lemus of the fulfilment of the mission (which can never be a criterion given the nature of scientific researich).

In turns out however, that science policy programmes and the social and cognive state of the sciences at which they are directed are not independent. sciemics pantisipate in the transformation processes that lead from external, political goals to silence policy programmes and their implementation, in : 4.1 a a ay as 10 adapt the political demands to the perceived scientific possibilitios Other adapt: tion processes within the political as well as the scientific aystems play also a iole. Conflict potential is reduced by this process of muual adaptation, but makes the task of the analyst who studies the impact of ohticial direction on science more difficult. The process has to be traced in letail (this has been done thoroughly for the case of environmen 391, but even then conclusions have to be based on comparisons with what uppened in other countries and counter-factual speculations about what culc have happened if institutiona! structures or cognitive developments ind been olverwise.

A nus "er of steps can be distinguished in the transformation process from extends goals to research regulatives. In fig. 3 the analytical scheme devel- 


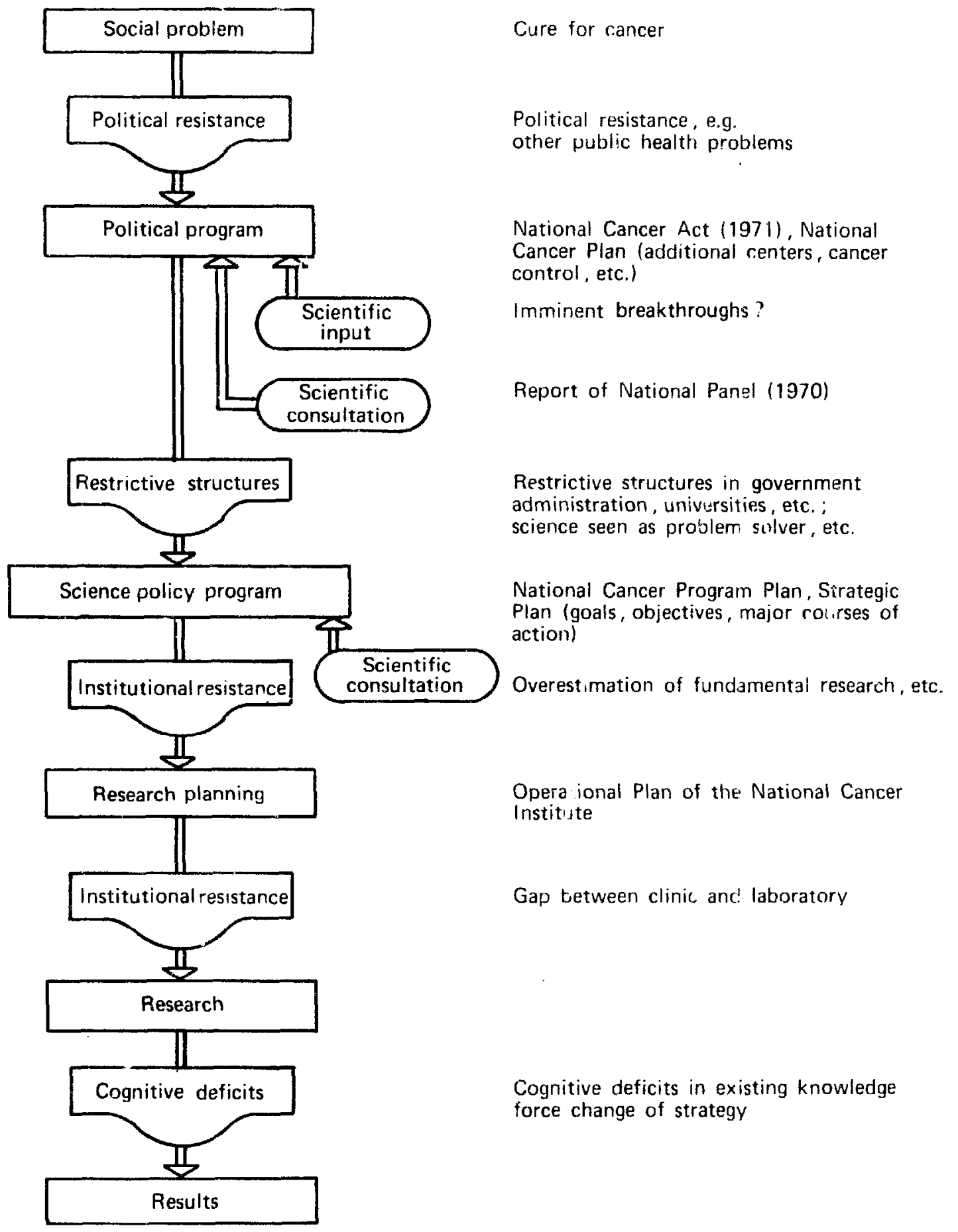

Fig. 3. The transformation of problems.

oped on the basis of the case studies is presented and illustrated with some of the steps taken in the course of creation and implementation of the National Cancer Program in the US [6, pp. 22-23; 40, p. 223]. The scheme consists of successive translations, which become transformations because of the intervening filters (labelled 'political resistance', 'restrictive structures, etc.). In addition, the most important scientific inputs are depicted. 
The social problem, the cure of cancer, is already the result of transformations of protlem definitions, e.g. the expectation of a cure based on the experience of cther successful therapies developed by medical science. To become transformed into a political programme, the social problem has to struggle for priority, in this case in public health policy. Besides the seriousness of the problem and the amount of lobbying, a scientific inpu is necessary: science should promise at least a partial solution in the near future. In the actual formulation of the political programme, scientific consultancy will influence which items are given prominence, and this will reflect the state of the art in the relevant disciplines, as well as their institutional strengths and weaknesses.

By sir gling out scientific research as providing the main answer to the po litical demand - which decision may have substantial reasons, but also just follow the trind of considering science as a catch-all problem solver, or be a manoeuvre to side-track the problem - the polit sal authority has to provide a translation into a science policy programme. $S_{r}$ ientific consultancy is very important here, and disciplinary and institutional divisions will determine part of the outcome. Administrative divisions and territorial struggles of government bureaucracies should not be underestimated, however (environmental programs are a clear example [39]). Lover down in the scheme the implementation of the science policy programm:e is iransformed by institutional resistances, traditional disciplinary attitudis, etc. as well as by the successes and failures in the ongoing research.

In the opening essay of Geplante Forschung, van den Daele, Krohn and Weingart emphasize (even more than in the earlier version [40]) the importance of so-called hybrid communities as the carriers of the mutual adaptation process between politics and science [41, pp. 26-27]. In many cases studied, groups were formed composed of scien ists, administrators and representatives of interest groups to effect the tran:lation/transformation of the political programme into the science policy pro.sramme, and sometimes also to act as advisory committees or steering groups. In the exceptions that are noted (fusion research, one of the information science programmes), one could still point out that those scientists were selected that had an affinity for policy maxing [42]. The hybrid communities, $c f$ which ihe officially constituted groups may form only a small, but visible part, are the carriers of the process of transformation from external goals to research regulatives, and may perhaps also keep the resaarch 'on track', i.e. take over the function of the traditional disciplinary communities. This will only happen, however, if a rew and and career structure can be created that is accepted by the scientists that are to $r$, the research. 
As overall conclusions from the set of case studies, van den Daele, Krohn and Weingart note two main points. First, that the appearance of hybrid communities is an indicator for an attempt at political direction of science, while its success depends on the institutionalization of the external regulatives in a manner compatible with the internal regulatives. Secondly, that the cognitive state of a discipline and the nature of its internal regulatives are independent variables determining the attitudes of scientists towards external orientation. This implies that resistance of scientists cannot always be reduced by the institutional measures that administrators can take (e.g. money, opportunities, career structures), and that science policy has to take the cognitive aspects of its policy object into account [41, pp. 34-35. 57]; compare also [35, p. 289].

\section{Concluding comments}

It was noted already that the studies in Geplante Forschung do not aim at a further articulation of the Srarnberg model. In spite of their heterogeneity of scientific fields studied : : - analytical frameworks used, however, an important commor! aspect can be singled out. All fields studied combine contributions from different traditional disciplines, and struggle with the problem of integrating ther., cogi vely as well as socially. Van den Daele, Krohn and Weingart view these problen-oriented fields as complementary to traditional disciplinary science [4i, pp. 55-59]. This implies to my mind that the concept of a fir lized science will only apply to contemporary problem-oriented science in a few e: cantional cases. The parent disciplines have to be oriented towards an exterial goal only in cooperation; that is to say, that instead of a guiding concepi (Anwendungsgrundlage) an integrating concept (Integrationsgrundlage) is necessary. The concept of an 'integrating concept' has been used by others in inother context [43], but I think it would be useful to exrend the Starnberg model in this way and see if some of its limitations can be overcome.

A difficulty that will remain, and one that has been criticized already, is the assumption that science is homogeneous. The assumption is facilitated by the physicalist-reductionist outlook. of the Starnberg group, which can al:o be recognized in some of the case studies in Geplante Forschung. Because of the more empirical approach in the case studies, the assumption does not pliy on impcotant role and, in fact, different kinds of disciplines are discussed. My impression is, however, that the case studies do suppose a social and political homngeneity of scienise, or at least neglect possible divisions in this respect (with the exception o: a few side-remarks in the study of heavy-ions research 
$[6$, p. 352]). With increasing democratization of decision-making, divisions due to social stratification in science (including the technical assistants) will mas. their infiuence feit. And the controversial nature of many science- andtechnology related decisions will activate latent political differences between jcientists, as has happened already with recombinant-DNA research and in the biomedical field [44].

The politicization of science policy will also influence the composition of the hybrid communities. Io obviate accusations of one-sidedness, advisory conmittees on recombi lant-DNA research have to contain at least one certified opponent. When th is trend continues, the study of hybrid communities will become an even more important tool for science policy studies than van den Daele, Krohn and Weingart have shown it to be.

In spite of its limitations, the Starnberg model has rendered an important service to science policy studies: it has focused attention on a cognitive approach to science policy. Geplante Forschung was inspired by it, and used some of its conceptual apparatus to demonstrate empirically that it is necessary to take cognitive factors into account in the analysis of science policy, and also, I would add, in science policy itself. A better model for the development of scientific fields has not been proposed, but it is more important to continue this research tradition. In terms of the Starnberg model, it is in its exploratory phase, and it may even be exploited lightly for the external goal of improving science policy.

\section{References}

1 I.S. Splegel-Rösing, Wissenschaltsentwicklıng und Wissens'haftssteuerung. Eirführung und Material zur Wissenschaftsforschung (Athenáum, Frankfurt a/klain, (1973), Abschnitt III.

[3] Gernot Bihme, Wolfgang van den Daele and Wolfgang Krohn, Alternatives in Science, International Journal of Sociology 8 (1978) 70-94; original German version Alternativen in der Wissenschaft, Zeitschrilt für Soziologie 1 (1972) 302316.

(1) Gernot Bolme, Wollgang van den Daele, Wolfgarg "rohn. Firalization in Scrence, Social Science Information 15 (1976) 307-330; slightly revised version of the origina! German article Die Finalisierung der Wissens:haft, Zeitschrift für Soziologie 2 (1973) 128144

[4] Gernot Böhme, Woltgang van ten Daele, Rainer Hohlfeld, Wolfgang Kroltr, Wolf Schäter and Tilman Spengler, Die gesellschaftiche Orientierung des wissenschaftlichen Fortschritts (Starnberger Studien 1) (Suhrkamp, Frankfurt a/Main, 1978); two chapters have appeared earlier in English versions, see 24$]$ and [25].

(5) Wolfgang van den Dacle and Peter Weingart, Resistance and Receptivity of Science to External Direction. The Emergence of New Disciplines under the Impact of Suence Policy, in Lenaine et al, infra [7, pp. 247-275]; original German version Resistenz und Rezep ivität der Wissenschait - Zu den Entstehungsbedingungen 
neuer Disziplirien durch wissenschaftspolitische Steuerung, Zeitschrift für Soziologie 4 (1975) $146-164$.

[6] Wolfgang van de Daele, Wolfgang Krohn, Peter Weingart (Hrsg.), Geplantc For. schung. Vergleichenie Studien über den Einfluss politiv her Programme auf die Wissenschaftsentwicklung (Suhrkamp, Frankfurt a/Main, 1979); an earlier, leduced version of the first chapter has appeared in English, see [40].

[7] See, for example, Gerard Lemaine, Roy MacLeod, Michael Mulkay and Peter Weingart (eds.), Perspectives on the Emergence of Scientific Disciplines (Mouton, The Hague and Paris, 1976) and David O. Edge and Michael Mulkay, Astronomy Transformed, The Emergence of Radio-Astronomy in Britain (John Wiley, New York, 1976).

[8] See for example Diana Crane, Invisible Colleges, Diffusion of Knowledge in Scientific Communities (University of Chicago Press, Chicago, 1972); also Arie Rip, Onderzoek naar de ontwikkeling van wetenschapsgebieden, Kennis en Methode (Boom, Meppel) 1 (1977) 311-338.

[9] See the journal Scientometrics (Elsevier Scientific Publishing Co., Amsterdam, and łakadémiai Kiadó, Budapest), published since 1978; and Citation Studies of Scientifăc Specialties, Special Issue of Social Studies of Science 7 (2) (May 1977).

[10] Barry Barnes, Scientific Knowledge and Sociological Theory (Routledge and Kegan Paul, London, 1974); Bruno Latour and Steve Woolgar, Laboratory Life. The Social Construction of Scientific Facts (Sage, Beverly Hills and London, 1979); Mary Douglas and David Ostrander (Eds.), Exercises in Cultural Analy sis (Basic Books, New York, forthcoming).

[11] Stuart S. Blume (ed.), Perspectives in the Sociology of Science (Johin Wiley, Chichester, 1977), especially the Introduction.

[12] Thomas S. Kuln, The Structure of Scientific Revolutions (University of Chicago Press, Chicago, 1962; 2nd ed. 1970).

[13] For example, Frarcis Crick, Central Dogma of Molecular Biology, Nature 227 (1970) 561-563.

[14 $\mathrm{j}$ Imre Lakatos and Alan Musgrave (eds.), Criticism and the Grow'th of Knowledge (Cambridge University Press, Cambridge, 1970).

[15] In [3] and [16, esp. pp. 207, 222-223]; they have not been successful, and have introduced additional social criteria like the absence of substaritive efforts to overhaul the fundamental theory.

[16] Gernot Böhme, Wolfgang varı den Daele and Rainer Hohlfeld, Finalisierung Revisited, in $[4$, pp. $195-250]$.

[17] It should be noted that finalization is used by the Starnberg group also in a broader sensc, to describe the harnessing of science to social and technological goals that has become increasingly important since the middle of the nineteenth century; see [3] and [18].

[18] Wolf Schäfer, Normative Finalisierung. Eine Perspektive, in [4, pp. 377-415].

[19] Gernot Böhme, Autonomisiering und Finalisierung, in [4, pp. 69-130].

[20] Thus, what is a finalized discipline when viewed from the side ',f : cience, is the paradigmatic phase of a new rechnical discipline, building on the 1 receding exploratory phase of hydraulics, from the perspective of technology. The sharacteristic feature, of the connection with mechanics remains, however, Sie further $[25$, pp. $240-243$ ]

[21] Günter Küppers, Fusionsforschung - Zur Zielorientierung im Bereicr: uer Grundlagenforschung, in [6, pp. 287-327].

[22] An example is provided by fusion research in the 1970 s, when experimental reactor designs had to be built and tested. This disrupted the work patterns and reward sys- 
Itin of thas fusm researchers, and measures had to be designed to keep the spe-

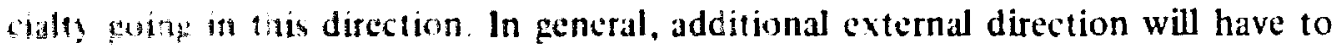
buth on waghts into the workings of the relevant scientific communities.

123 Itank R. Ptetsh. It:e 'I inalization' Debatt in Germany: Sunc Comments and Foplanations, Social Studies of Science $9(19 ; 9,115-124$.

$12+4$ Wolfong Kolm and Wolf Schafer. The Origins and Structure of Agricultural Chemistry, in lemaine a al. op. cit. $17, \mathrm{pp} .27-52\}$; the German version, Ursprung und Sirukiur det Aprikulturdtemie, in 14, pp. 23-63].

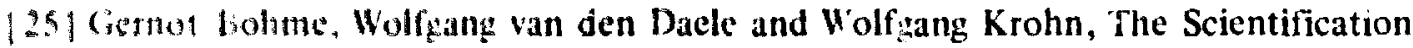
of Teshology. in Wolfgang Krohn, Edwin T. Lay ton, Jr. and Peter Weingart (eds.), The Dynamics of Science and Technology (Sociclogy of the Sciences, Yearbook 1978) (Reidel. Dordrecht. 1973), pp. 219-250; the German version, Die Verwissenstafilichung von Technologie, in [4, pp. 339-375].

[20) Grnot Bohme. Wolfgang van den Daele and Wolf șang Krohn, Experimentelle PhiWowhie Lisprunge autonomer Wissenschaftsentwicklung (Suhrkamp, Frankfurt a Man. 977): onle chapter has been published in I nglish, see [27].

12:| Hollgani vati den Dacle. The Social Construction of Science: Institutionalisation and Detinition of Positive Science in the Latter Half of the 17th Century, in: Lveret Mendelsohn, Peter Weingart and Richard Whitley (eds.), The Social Pruduction of Scientific Knowledge (Sociology of the Sciences, Yearbook 1977) (Reidel, Dordrech, 1977), pp. 27-54; the German version, Die soziale Konstruktion der Wissenschaft - Instiiutionalisierung und Definition der positiven Wissenschaft in det zusiten Halfte des 17. Jahrhunderts, in [26, pp. 129-182].

[2 1 ) Ron Jolanston, I inalization: A New Start for Science Policy?, Social Science Information 15 (1976) $331 \cdots 336$.

12 | Compas $\{16 . p$ p. 221 223| in combination with p. 202 on the competent judgement of physicists as a criterion for the closed character of the theory of quantum mechancs.

[301 Kaner Hohlfeld. Praxisbezuge wissenschaftlcher Disziplinen. Das Beispiel der hrebsforshun: in [4, pp. 131-193].

131) Naus buchholz, Die [ezielte Forderung und Entwicklung der Biotechnologie, in [6. 17.04116$]$.

132) Joln M.D. Symes, Policy and maturity in scence, Social Science Information 15 (1976) $337-347$.

13.31 Ron Jomston and Tom Jagtenberg, Goal Dire:tion of Scientific Research, in: Wolfgang Krolun, Fdwin T. Lay ton, Ir. and Peter Weingart (eds.), The Dynamics of Science and Technology (Sociology of the Sciences, Yearbook 1978) (Reidel, Dorducht. 19"8), pp. $29-58$.

134] Yan den Daek, Krolun and Weingart [41, p. 45] note $\mathrm{h}$ ow the American National cancer Program Plan allows cell biology the treedom of autonomous development, is befis a discipline in the pardigm stage.

[35] So [2!, pp. 289, 304-308].

136| Arie Rip en Walter van der Es, Biotechnologic: Ontwikkeling en sturende impulsen, 11.: Arce Rip en Peter (roeneweger. (red.), Macht over kennis, Mogelijkheden van wetenchapsbeleid (Samson, Alphen a/d Rijn, 1980).

[37] Ur,puclished study, Chemistry and Society, Leiden (1979). Some results are presented in Arie Rip, Science Policy and the Scientific Picture of the World, in: W. Callebaut, M. de Mey, R. Pinxten and F. Vandimme (eds.), Theory of Knowledge and Si ience Policy (Communication and Ccgnition, Ghent, 1979), pp. 358-377; they 1 ave been used in a hearing of the Dutch ('hemistry Survey Committea of the Ministy of Science Policy. 
[38] Rainer Hohlfeld, Strategien gegen den Krebs - Die Planung der Krebsiorschun! , in [6,pp. $181-238]$.

[39] Günter Küppers, Peter Lundgreen and Peter Weingert, Umweltforschun: die gesteuerte Wissenschaft? (Suhrkamp, Frankfurt a/Main, 1978).

[40] Wolfgang van den sidele, Wolfgang Krohn and Peter Weingart, The Political Direction of Scientific Development, in: Everett Mendelsohn, Peter Weingart and Richard Whitley (eds.), The Social Production of Scientific Knowledge (Sc :iology of the Sciences, Yearbook 1977) (Reidel, Dordrecht, 1977), pp. 219-242.

[41] Wolfgang van den Daele, Wolfgang Krohn and Peter Weingart, Die folitische Steuerung der wissenschaftlichen Entwicklung, in [6, pp. 11 -63].

[42] As is pointed out for top science policy advisory councils by Ronald Brickman and Arie Rip, Science Policy Advisory Councils in France, The Netherlands and the United States, 1957-77. A Comparative Analysis, Social Studies of Science 9 (1979) 167-198. p. 180.

[43] Basil Bernstein, On the Classification and Framing of Educational Knowledge, in idem, Class, Codes and Control, Vol. 1 (Routledge \& Kegan Paul, London, 1971). Paladin editio.1 (1973) pp. 227-256; David Edge, On the Purity of Science, in: W. Roy Niblett (ed.), The Sciences, the Humanities and the Technological Threat (University of Landon Press, London, 1975), pp. 42-64.

[44] Dorothy Nelkin (ed.), Controversy. Politics of Technical Decisions (Sage, Beverly Hills and Lonåon, 1979) 